\title{
13.
}

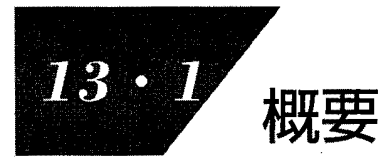

\section{3-1・1 研究活動}

機械力学・計測制御部門（以下，本部門）は，いわゆる四力 学の一つである機械力学に加え, 計測, 制御の各分野を基盤と している. 本部門では，各分野の学術的な基盤研究から実践的 な応用への研究や，他部門との連携による新領域まで幅広く研 究が行われ，その研究成果が積極的に公開されている.ここで は，2013 年 1 月〜 12 月に発行された本会論文集 C 編につい てまとめ，また講演会・講習会などの状況について述べる.

この 1 年間, 機械力学・計測・制御分野に関し本会論文集 C 編に揭載された一般論文は 200 編に及んでいる（図 1)。同論 文集 5 月号（Vol.79，No.801）では，2012 年に開催された D\&D 特集号が組まれ，35 編の論文が揭載された．D\&D 講演 会での発表が，論文集への揭載機会として機能しており，質の 高い論文の公開が促進される一因ともなっている．また，本部 門が編集する英文誌である Journal of System Design and Dynamics（JSDD）に関し，2013 年には 5 号が刊行され，38 編 の論文が揭載されている. D \& D 特集号の論文の一部は, JSDD Special Issue on D\&D 2012 にも英文論文として掲載さ れ，本部門研究活動の海外発信媒体として貢献している.

研究対象としては，鉄道，エレベータ，自動車，人工衛星, ロボティクスなど多岐にわたり，例年に引き続き多くの論文が 投稿されている．振動扣よび運動に関する制御技術が提案され ており，制振技術や走行安定性に関する研究が数多く報告され ている，とくに，位置決め制御，軌道制御などのロボティクス 関連の技術に関する研究について多数投稿されている.

バイオ関連の研究では, 2012 年に引き続きバイオ系の境界 領域に扣ける研究論文が多数投稿されている. 人間工学, 福祉 工学やスポーツ工学などを対象とした研究がなされており，眼 球，軟骨，肩甲骨，膝関節，動脈，指尖部，胸骨などの特性に 関する研究や歩行解析, 歩行アシスト, 離床行動, 車いすなど の福祉工学に関する解析，乗り心地など自動車運転についての 評価が行われている.

制御については，アクティブ制振や運動制御に関して，非線 形制御やモデル予測制御などの検討が行われている.

音響関連の研究では，アクティブノイズコントロールを始め として, FEM (Finite Element Method) とSEA (Statistical Energy Analysis）の統合による解析など，音響解析手法に関

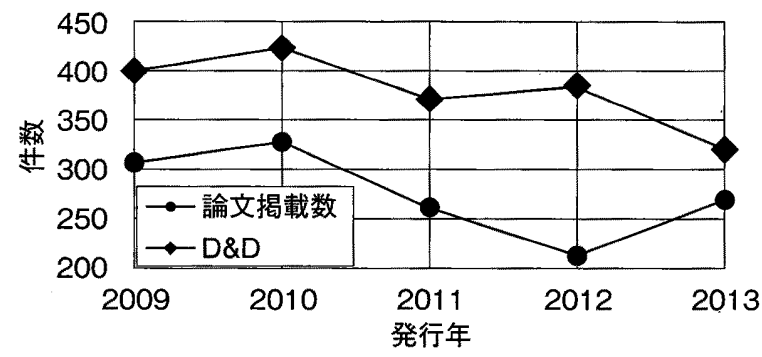

図 1 論文数, 発表数
して積極的に研究がなされている.

そのほか, モニタリングに関して，半導体ウェー八，加工工 具などを対象に研究されており, 応力発光体, カオス応答アト ラクタによる手法などが検証されている，流体関連振動に関し ては，数值解析から実験的検討まで幅広く行われた。マルチボ ディダイナミクスに関する研究も引き続き行われており，柔軟 マルチボディシステムに関する研究などが対象となっている.

上記研究は総じて, 基盤的研究から応用的研究まで幅広く力 バーされ，新領域への拡大も積極的に試みられており，本部門 における論文実績として特筆される。

\section{3·1.2 講演会, シンポジウム, 講習会など}

2013 年においても，D\&D2013 講演会が本部門活動の中心的 な役割を果たした。同講演会は，2013 年 8 月 26 日から 30 日 までの期間，九州産業大学を会場とし，MoViC2013（8月 27 日〜 30 日) との共催で開催された. 参加者は累計 713 名となっ た. 本部門における研究活動における交流の場として機能して おり，一般講演 469 編の研究発表が行われた．振動・音響関 連分野のほかに, マルチボディダイナミクス,リハビリテーショ ン，ヒューマンダイナミクスなどの領域においても多くの講演 がなされた，また，例年同講演会で行われている振動工学デー タベースフォーラムも開催され, 32 件の事例紹介が行われた. 回転機械，流体関連振動，交通機械，プラント，橋梁など幅広 い分野での振動・音響対策の事例が紹介されている.

シンポジウムとして，第 25 回「電磁力関連のダイナミクス」 シンポジゥム（5月15日～17 日，参加者 192 名）が箱根ホ テル小涌園にて開催された。 また，2013 年度は本会が幹事学 会として，自動制御連合講演会（11月 16 日〜 17 日，参加者 566 名）が，新潟大学工学部にて開催された，加えて，評価・ 診断に関するシンポジウム (12月 2 日〜 3 日, 参加者数 84 名) が名古屋国際会議場にて開催された.いずれのシンポジウムも, 2013 年度まで継続して多くの開催を重ねており，定着度の高 いシンポジゥムとなっている.

国際交流活動として，本部門では1998 年度より韓国機械学 会機械力学・制御部門との交流事業を開催している. 隔年のシ ンポジウムの開催，間の年には相互の研究者がそれぞれの部門 講演会に参加し, 講演を行うこととしている. 2013 年度は, 本部門の部門講演会である D\&D2013 講演会において, JapanKorea Joint Symposium on Dynamics \& Control (8月 27 日〜 28 日, 参加者数 50 名) を開催した.

本部門が主催する講習会として,振動モード解析実用入門(受 講者 53 名)，マルチボディシステム運動学の基礎（受講者 27 名), マルチボディシステム動力学の基礎（受講者 20 名）, 計 算力学技術者 2 級認定試験対策講習会（関東地区：受講者 29 名, 東海地区 : 受講者 10 名), 回転機械の振動と HIL 実習 (受 講者 40 名）が行われた. これらの講習会は，一定の受講者数 を集めており,本部門の講習会として重要な役割を果たしている.

〔梶原 逸朗 北海道大学〕

\section{$13 \cdot 2$ 力学系理論 $\cdot$ 応用}

力学系理論とその応用に関する研究はもともと天体力学から 発展してきたこともあり, 数学や物理学における理論研究が先 